\title{
シミュレーティッド・アニーリング法による フロー・ショップ・スケジューリング*
}

\author{
石 㴊久生 ${ }^{* *}$ ・田村亮二** -田中英 ${ }^{* *}$
}

\section{Flow Shop Scheduling by Simulated Annealing*}

\author{
Hisao Ishibuchi ${ }^{* *}$, Ryoji TAMUrA ${ }^{* *}$ and Hideo TANAKA ${ }^{* *}$
}

In this paper, we apply the simulated annealing algorithm to the flow shop scheduling problem with an objective of minimizing the makespan and show its power as an approximate algorithm by the numerical experiment on randomly generated test problems. In the numerical experiment, we compare the simulated annealing algorithm with the other approximate algorithms including the RAES algorithm proposed by Dannenbring, its slightly modified algorithm, a random search algorithm and a local search algorithm. We also show that the performance of the simulated annealing algorithm depends on the choice of a neighborhood structure.

\section{1. 緒 言}

近年, 組合せ最適化問題に対する有効な解法として, Kirkpatrick ら および Cerny ${ }^{2}$ により提案されたシミュ レーティッド・アニーリング法（SA 法）が注目を集め ている.SA 法注局所探索を基本としているが，目的関 数の值が恚くなる状態への状態推移も確率的に許すこと により，局所最適解に陷ることなく，大域的最適解に近 い良好な解を求めるてとのできる方法であるとされてい る. いま, 目的関数 $f$ の最小化を考えれば, 状態 $\boldsymbol{x}$ か ら状態 $\boldsymbol{y}$ への推移確率は, 次の受理確率により与えら れる.

$$
p(\boldsymbol{x} \rightarrow \boldsymbol{y})=\min \left\{1, \exp \left(\frac{f(\boldsymbol{x})-f(\boldsymbol{y})}{c}\right)\right\}
$$

すなわち, $f(\boldsymbol{x}) \geqq f(\boldsymbol{y})$ のときは常に状態 $\boldsymbol{y}$ は受理 され, $f(\boldsymbol{x})<f(\boldsymbol{y})$ のさき (1) 式の指数関数部分に より与えられる確率で状態 $\boldsymbol{y}$ が受理される. ごてで $c$ は，物理的な焼きなまし (Annealing) における温度に 対応した正の制御変数である. この $c$ の值が大きい状態 では,ほとんどすべての状態が受理され, $c$ の值が非常に 小さい状態では, 目的関数の值が増加する状態はほとん

* 原稿受付 1990. 3. 6

** 大阪府立大学 工学部 University of Osaka Prefecture ; Mozu-Umemachi, Sakai 591, JAPAN

Key Words : scheduling, simulated annealing, combinatorial optimization, computational analysis, approximate algorithm.
ど受理されない. SA 法では, 局所最適解に陥ることな く最適解に近い良好な解を得るため; 高温の状態から $c$ の値を徐々に小さくするという方法が取られている1 ${ }^{1}$.

このとき, 制御変数 $c$ の初期值と減少方法がある条件を 満たせば, SA 法により確率 1 で最適解が得られること が, Geman \& Geman ${ }^{3}$ により証明されている.さら に, SA 法により確率 1 で最適解が得られるための必要 十分条件が, Hajek ${ }^{4}$ により示されている.

$\mathrm{SA}$ 法は, プログラム化が容易であることと, 問題領 域に対する深い知識が不要であるてとから, 多くの組合 せ最適化問題に応用されている ${ }^{5,6}$. また, 非線形計画問 題の最適化手法としての一般化 ${ }^{7,8}$ あ行なわれており, Matsuba ${ }^{9}$ では, Hopfield 回路 ${ }^{10,11}$ への応用屯示され ている.

本研究では, 総処理時間最小化を目的としたフロー・ ショップ・スケジューリング問題に対する近似解法とし ての SA 法の有効性を示すため, SA 法と従来の近似解 法との比較を行なう。乙のとき, 比較対象の近似解法と しては, Dannenbring ${ }^{12}$ による RAES 法, RAES 法 の改良手法, 初期值をランダムに与えた局所探索法, ラ ンダム・サンプル・スケジューリング法などを用いた。

SA 法を用いたスケジューリング問題に関する研究と しては, Laarhoven $ら^{13}$ によるジョブ・ショップ・ス ケジューリング問題への適用が行なわれ, 従来の近似解 法との比較が行なわれている. Laarhoven ら ${ }^{13}$ では, SA 法により従来の近似解法よりあ良い解が得られるが, 
より多くの計算時間が必要であるという結果が得られ ている.しかし，現実の問題に適用するためには，事前 に設定された計算時間内でのアルゴリズムの性能が問題 となる. すなわち，ジョブ数が数 10 ジョブから 100 ジョ ブという大規模なフロー・ショップ・スケジューリング 問題を，廉価なコンピュータを用いて解かなければなら ないという現実問題への応用を考えれば，少ない計算量 でのアルゴリズムの性能が非常に重要な問題となる。 そ こで本研究では, 計算時間を事前に設定できるSA 法ア ルゴリズムを用いるととにより，様々な計算時間での $\mathrm{SA}$ 法の性能を調へ，従来の近似解法との比較を行なう。

また，近傍構造の選び方が SA 法の性能に大きな影響 を与えるということが, Cerny²によりすでに指摘され ている. そてで本研究では, 三つの異なる近傍構造を用 いた SA 法の性能を評価するてとにより，近傍構造の選 び方と SA 法の性能との関係も明らかにする.

\section{2. 問題の定式化とその近似解法}

\section{1 問題の定式化}

フロー・ショップ・スケジューリング問題は, $m$ 個 の工程により順に加工される $n$ 個のジョブの加工順序 を決める問題である. 本研究では, すべての工程で同じ 順序で $n$ 個のジョブが加工されるとし，乙の加工順序 をべクトル $\boldsymbol{x}=\left(x_{1}, x_{2}, \cdots, x_{n}\right)$ で表わすととにする. ただし, 要素 $x_{k}$ は, $k$ 番目に加工されるジョブの番号 を表わす。

工程 $i$ 亿怙けるジョブ $j$ の加工時間を $t_{p}(i, j)$, 加工 終了時間を $t_{f}(i, j)$ とすると, 加工順序 $\boldsymbol{x}$ での総処理 時間 $f(\boldsymbol{x})$ は次のように計算される ${ }^{14}$.

$$
\begin{aligned}
& t_{f}\left(1, x_{1}\right)=t_{p}\left(1, x_{1}\right) \\
& t_{f}\left(i, x_{1}\right)=t_{f}\left(i-1, x_{1}\right)+t_{p}\left(i, x_{1}\right) \\
& \text { for } i=2,3, \cdots, m \\
& t_{f}\left(1, x_{k}\right)=t_{f}\left(1, x_{k-1}\right)+t_{p}\left(1, x_{k}\right) \\
& \text { for } k=2,3, \cdots, n \\
& t_{f}\left(i, x_{k}\right)=\max \left\{t_{f}\left(i-1, x_{k}\right), t_{f}\left(i, x_{k-1}\right)\right\} \\
& +t_{p}\left(i, x_{k}\right) \\
& \text { for } i=2, \cdots, m, k=2, \cdots, n \\
& f(\boldsymbol{x})=t_{f}\left(m, x_{n}\right)
\end{aligned}
$$

すなわち，最終工程における最後のジョブの加工終了 時間が総処理時間 $f(\boldsymbol{x})$ となる.

総処理時間最小化を目的としたフロー・ショップ・ス ケジューリング問題は，(2)〜 (6) 式により計算される $f(\boldsymbol{x})$ が最小になるような $n$ 個のジョブの加工順序 $\boldsymbol{x}$ を 求める問題である. 総処理時間の最小化を目的としたフ ロー・ショップ・スケジューリング問題は, 2 工程の場
合では, Johnson ${ }^{15}$ の方法により簡単に最適解を求め ることができる. しかし，一般の多工程の場合では，特 にジョブ数が多くなると, 最適解を求めることは非常に 困難になる。そのため，多くの近似解法が提案されてお り, Dannenbring ${ }^{12}$ によるRAES 法が最も有効である とされている12,16.

\section{2 Dannenbring による RAES 法 ${ }^{12}$}

Dannenbring ${ }^{12}$ は, ランダムに生成された数多くの 問題例を解くことにより, 彼自身の提案手法である RAES 法 (Rapid Access with Extensive Search 法）が，総処理時間最小化を目的としたフロー・ショッ プ・スケジューリング問題に対して非常に有効な手法で あることを示した.

RAES 法は, 巧妙に初期解の設定を行なった局所探 索法と見なすととができる，RAES 法におりる初期解 の設定は, RA 法 (Rapid Access 法) と呼ばれる次の ような方法により行なわ机る。

(1) $j=1,2, \cdots, n$ に対して, $t_{p}^{\prime}(1, j), t_{p}^{\prime}(2, j)$ を次式 により定める.

$$
\begin{aligned}
& t_{p}^{\prime}(1, j)=\sum_{i=1}^{m}(m-i+1) \cdot t_{p}(i, j) \\
& t_{p}^{\prime}(2, j)=\sum_{i=1}^{m} i \cdot t_{p}(i, j)
\end{aligned}
$$

（2）第 1 工程の加工時間が $t_{p}^{\prime}(1, j)$ であり, 第 2 工程 の加工時間が $t_{p}^{\prime}(2, j)$ である 2 工程 $n$ ジョブ問題に対 し, Johnson ${ }^{15}$ の方法を適用するととにより得られるジョ ブの加工順序を $\boldsymbol{x}_{R A}$ とする.

乙のようにして得られる解 $\boldsymbol{x}_{R A}$ が，RAES 法に打け る初期解となる. RAES 法では, 乙の初期解を用いて 局所探索が行なわれる. 乙の局所探索は, 次のような近 傍構造に基づき行なわれる。

$$
\begin{array}{r}
S_{1}(\boldsymbol{x})=\left\{\boldsymbol{y}=\left(x_{1}, \cdots, x_{k-1}, x_{k+1}, x_{k}, \cdots, x_{n}\right)\right\} \\
k=1,2, \cdots, n-1\}
\end{array}
$$

すなわち, 解 $\boldsymbol{x}$ の近傍 $S_{1}(\boldsymbol{x})$ が隣接する 2 ジョブの 交換により定義され，(9) 式は $x_{k}$ と $x_{k+1}$ が交換されて いることを表わしている。な技，近傍 $S_{1}(\boldsymbol{x})$ の濃度は $(n-1)$ である. 近傍 $S_{1}(\boldsymbol{x})$ の濃度がジョブ数 $n$ の 1 次 のオーダであることから, 本研究では, 近傍の大きさを 表わすための添字 1 を用いている.

$R A$ 法により得られた解 $\boldsymbol{x}_{R A}$ と (9) 式により定義さ れた近傍構造. $S_{1}(\boldsymbol{x})$ を用いれば, RAES 法は次のよう なアルゴリズムとして表わすととができる。な打本研究 では，近傍構造 $S_{1}$ を用いた方法であるということを明 確にするため, Dannenbring ${ }^{12}$ の RAES 法を, 今後 $\mathrm{RAES}-S_{1}$ 法と呼ぶととにする. 
【RAES- $S_{1}$ 法アルゴリズム ${ }^{12} 】$

Step $1 \boldsymbol{x}:=\boldsymbol{x}_{R A}$ とする.

Step 2 次式を満たす $\boldsymbol{y}^{*}$ を求める.

$$
f\left(\boldsymbol{y}^{*}\right)=\min \left\{f(\boldsymbol{y}) \mid \boldsymbol{y} \in S_{1}(\boldsymbol{x})\right\}
$$

Step $3 f\left(\boldsymbol{y}^{*}\right)<f(\boldsymbol{x})$ ならば, $\boldsymbol{x}:=\boldsymbol{y}^{*}$ として Step 2へ戻る. $f\left(\boldsymbol{y}^{*}\right) \geqq f(\boldsymbol{x})$ ならば計算を終了 する.

\section{3 RAES 法の改良}

Dannenbring ${ }^{12}$ の RAES- $S_{1}$ 法は, 小さな近傍構造 を用いているため，短い計算時間で実行するてとができ る. また，初期解の選び方が巧妙であるため，短い計算 時間で比較的良好な解を得ることができる. しかし，計 算時間に余裕がある場合では，より大きな近傍構造を用 いることにより，RAES- $S_{1}$ 法よりあ良い解を得るこ とができる.

ここでは，任意に選ばれた 2 ジョブの交換に基づく近 傍構造を用いることにより, Dannenbring ${ }^{12}$ の RAES$S_{1}$ 法の改良方法を示す.

近傍構造 $S_{1}$ は, 隣接する 2 ショョブの交換により定義 されていたが，乙てでは，任意に選ばれた 2 ジョブの交 換に基づく近傍構造 $S_{2}$ を次のように定義する.

$$
\begin{aligned}
S_{2}(\boldsymbol{x})=\{\boldsymbol{y} & =\left(y_{1}, \cdots, y_{n}\right) \mid \boldsymbol{y} \neq \boldsymbol{x} \text { and } \\
x_{j} & \left.=y_{j} \text { for at least }(n-2) j^{\prime} s\right\} \text { (11) }
\end{aligned}
$$

このように定義された近傍 $S_{2}(\boldsymbol{x})$ の濃度は, ${ }_{n} C_{2}=$ $n(n-1) / 2$ であり, ジョブ数 $n$ の 2 次のオーダとなっ ている.

近傍構造 $S_{2}$ を用いれば, RAES- $S_{1}$ 法アルゴリズム のStep 2 に扔ける (10) 式は, 次のようになる.

$$
f\left(\boldsymbol{y}^{*}\right)=\min \left\{f(\boldsymbol{y}) \mid \boldsymbol{y} \in S_{2}(\boldsymbol{x})\right\}
$$

本研究では，(12）式を用いた RAES 法をRAES- $S_{2}$ 法と呼ぶことにする.

さらに，任意に選ばれた 3 ジョブの交換に基づく近傍 構造 $S_{3}$ を, 2 ジョブの交換により生成される近傍構造 $S_{2}$ を包含するように，次のように定義する.

$$
\begin{aligned}
S_{3}(\boldsymbol{x})= & \left\{\boldsymbol{y}=\left(y_{1}, \cdots, y_{n}\right) \mid \boldsymbol{y} \neq \boldsymbol{x}\right. \text { and } \\
& \left.x_{j}=y_{j} \text { for at least }(n-3) j^{\prime} s\right\} \text { (13) }
\end{aligned}
$$

てのように定義された近傍 $S_{3}(\boldsymbol{x})$ の濃度は, ${ }_{n} C_{2}+$ $2{ }_{n} C_{3}=n(n-1) / 2+2 n(n-1)(n-2) / 6$ であり, ジョ ブ数 $n$ の 3 次のオーダとなっている.

理論的には，(13）式による近傍構造 $S_{3}(\boldsymbol{x})$ を用いれ ば，RAES- $S_{1}$ 法や RAES $-S_{2}$ 法よりあよい解が得ら れると考えられる。しかし，計算時間の点で現実的では ないため, 本研究では RAES- $S_{3}$ 法への拡張は行なお ないととにする.

\section{4 局所探索}

RAES $-S_{1}$ 法抒よび RAES $-S_{2}$ 法では，初期解の設 定を RA 法之呼ばれる方法で行なった。しかし，一般 の組合せ最適化問題では，RA 法のような巧妙な初期解 の設定方法が存在しない場合も多い，そのような場合で は，次に示す局所探索アルゴリズムを利用可能な計算時 間内で繰り返すてとにより，良好な解を得ることができ る.

\section{【局所探索アルゴリズム】}

Step 1 初期解 $x$ をランダムに設定する.

Step 2 次式を満たす $\boldsymbol{y}^{*}$ を求める.

$$
f\left(\boldsymbol{y}^{*}\right)=\min \{f(\boldsymbol{y}) \mid \boldsymbol{y} \in S(\boldsymbol{x})\}
$$

Step $3 f\left(\boldsymbol{y}^{*}\right)<f(\boldsymbol{x})$ ならば, $\boldsymbol{x}:=\boldsymbol{y}^{*}$ として Step 2 へ戻る. $f\left(\boldsymbol{y}^{*}\right) \geqq f(\boldsymbol{x})$ ならば計算を終了 する.

なお，近傍構造としては，(9) 式による $S_{1}(\boldsymbol{x})$ および （11）式による $S_{2}(\boldsymbol{x})$ を用いるととにする.

\section{Simulated Annealing 法}

SA 法を組合せ最適化問題の近似解法として用いる場 合，次のようなことが問題となる.

(1) 近傍構造の選び方

（2）制御変数 $\boldsymbol{c}$ の冷却スケジュール，すなわち，制御 变数 $\boldsymbol{c}$ の初期值, 減少方法および最終値の選び方

本研究では, 近傍構造として 2. で示した三つの近傍 構造を用い, 近傍構造の選び方と SA 法の性能との関係 を調べるととにする.

一方, 制御变数 $c$ の冷却スケジュールとしては, Lundy ら ${ }^{17}$ により提案された方法を用いた. Lundy $ら^{17}$ によ る冷却スケジュールを用いた SA 法アルゴリズムは, 次 のように表わすことができる.

\section{【SA 法アルゴリズム：繰り返し数 $N$ 】}

Step 1 初期解 $\boldsymbol{x}$ をランダムに設定する.

$$
i:=0, c_{i}:=c_{0} \text { とする. }
$$

Step 2 近傍 $\boldsymbol{S}(\boldsymbol{x})$ の中から候補解 $\boldsymbol{y}$ をランダムに 選び出す.

Step $3 f(\boldsymbol{y}) \leqq f(\boldsymbol{x})$ ならば, $\boldsymbol{x}:=\boldsymbol{y}$ とする. $f(\boldsymbol{y})>f(\boldsymbol{x})$ の場合は, 次式が成り立つと きにのみ $\boldsymbol{x}:=\boldsymbol{y}$ とする.

$$
\operatorname{RND}[0,1)<\exp \left(\frac{f(\boldsymbol{x})-f(\boldsymbol{y})}{c_{i}}\right)(15)
$$

ただし，RND $[0,1)$ は，区間 $[0,1)$ 内の一様 乱数である.

Step $4 \quad c_{i+1}:=c_{i} /\left(1+\beta c_{i}\right)$ とする.

Step $5 i:=i+1$ とする. 
Step $6 i=N$ ならば，計算を終了する， $i<N$ な らば, Step 2 へ戻る.

ここで， $c_{0}, \beta, N$ は，事前に設定しなければならない パラメータである.

なお, Lundy ら ${ }^{17}$ では明示されていないが, Step 4 における制御変数の減少関数は, 次のように書き換える ことができる.

$$
c_{i+1}=c_{0} /\left(1+(i+1) \beta \mathrm{c}_{0}\right)
$$

したがって, 制御変数の最終值 $c_{f}$ は次のようになる.

$$
c_{f}=c_{0} /\left(1+N \beta c_{0}\right)
$$

このとき， $c_{0}$ が十分に大きいときには，近似的に次式 が成り立つ.

$$
c_{f} \approx 1 / N \beta
$$

本研究では, 現実問題への適用の容易さという点を重 視し, Lundy $ら^{17} に よ り$ 提案された冷却スケジュール を用いた. 具体的には，以下のような理由による.

\section{（1）アルゴリズムの単純さ}

アルゴリズムが単純であるので，プログラム化が容易 である。

\section{（2）パラメータ設定の容易さ}

上述のアルゴリズムに打ける制御変数 $c$ の值の変化を 図示すると，Fig.1のようになる。乙の図からわかる ように, 制御変数 $c$ はその值が大きいときには非常に早 く減少するため, 初期値 $c_{0}$ を十分に大きく取ることが できる. また，アルゴリズムの繰り返し数 $N$ は利用可 能な計算時間により規定される。したがって, 問題と なるのは, パラメータ $\beta$ の值のみである. $\beta$ の值は, $f(\boldsymbol{x})<\boldsymbol{f}(\boldsymbol{y})$ のとき, 次の受理確率が 0 に近い值になる ように，(18）式を用いて選べばよい.

$$
p(\boldsymbol{x} \rightarrow \boldsymbol{y})=\min \left\{1, \exp \left(\frac{f(\boldsymbol{x})-f(\boldsymbol{y})}{c_{f}}\right)\right\}
$$

なお, $f(\boldsymbol{x})<f(\boldsymbol{y})$ のときの受理確率は,

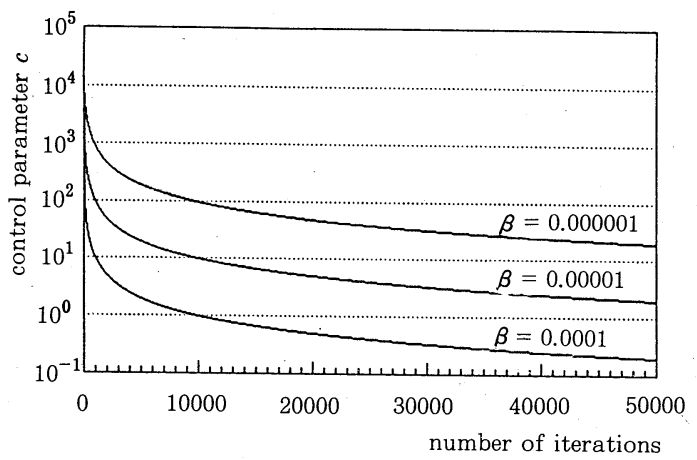

Fig. 1 Shape of the decrement function $c_{i+1}=c_{i} /\left(1+\beta c_{i}\right)$ where $c_{0}=10000$

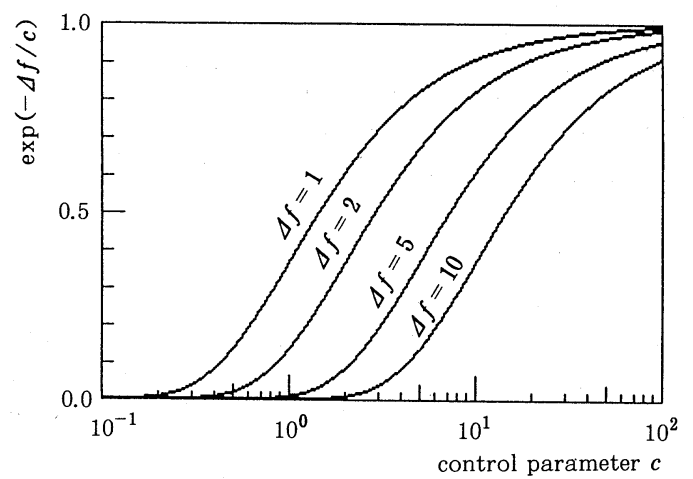

Fig. 2 Shape of the acceptance probability $\exp (-\Delta f / c)$ where $\Delta f=f(y)-f(x)$

$$
\begin{aligned}
& p(\boldsymbol{x} \rightarrow \boldsymbol{y})=\exp (-\Delta f / c) \\
& \Delta f=f(\boldsymbol{y})-f(\boldsymbol{x})
\end{aligned}
$$

と表わすととができ，乙れを $\Delta f=1,2,5,10$ として図 示すれば Fig. 2 のようになる.

\section{（3）短い計算時間内での実行可能性}

上述のアルゴリズムでは，アルゴリズムの繰り返し数 $N$ を事前に任意の回数に設定できる. このため, 非常 に短い計算時間内での実行屯可能であり，他の近似解法 と計算時間を同一にした比較が可能となる.

本研究では, 上述の理由により, Lundy $ら^{17}$ による冷 却スケジュールを用いた. Lundy $ら^{17}$ による冷却スケ ジュールを用いた SA 法に関する研究としては, Eglese $ら^{18}$ による時間割り作成問題への応用がある.

冷却スケジュールは，SA 法の性能に非常に大きな影 響を与えるため, 様々な方法が提案されている（詳しく は, Laarhoven $ら^{5}$ な゙゙を参照). したがって，本研究 で対象としているフロー・ショップ・スケジューリング 問題に対して最あ適した冷却スケジュールを調べるとと あ, 非常に重要な問題であり, 今後の課題である.

\section{4. 数值実験の結果}

\section{1 実験条件}

工程数を 10 工程とし, 総ジョブ数を 20,40 および 60 とした 3 種類の規模の問題を対象に，それぞれ 10 個の 問題例を作成した. このとき, 加工時間は，区間 $[1,99]$ 内の整数值とし，乙れを一様乱数で与えた．乙のような 条件のもとで作成された 30 個の問題例に対し, 次のよ うな方法を適用した。

（1）ランダム・サンプル・スケジューリング法 (RSS 法）

(2) Dannenbring ${ }^{12}$ による RAES 法 (RAES- $S_{1}$ 法) 
石判・田村・田中：シミュレーティッド・アニーリング法によるフロー・ショップ・スケジューリング

（3）近傍構造 $S_{2}$ を用いた RAES 法（RAES- $S_{2}$ 法）

（4）近傍構造 $S_{1}$ を用いた局所探索（LS- $S_{1}$ 法）

（5）近傍構造 $S_{2}$ を用いた局所探索（LS- $S_{2}$ 法）

（6）近傍構造 $S_{1}$ を用いた SA 法（SA- $S_{1}$ 法）

(7) 近傍構造 $S_{2}$ を用いた $\mathrm{SA}$ 法 $\left(\mathrm{SA}-S_{2}\right.$ 法)

（8）近傍構造 $S_{3}$ を用いた $\mathrm{SA}$ 法（SA-S $S_{3}$ 法）

これらの手法の比較のため, ランダム・サンプル・ス ケジューリング法において 50,000 回のランダム・サンプ ルにより得られた解 $\boldsymbol{x}_{\mathrm{RSS}}$ を基準として, 他の手法で得 られた解 $\boldsymbol{x}$ の性能を表わす相対的総処理時間 $g(\boldsymbol{x})$ を, 次のように定めた。

$$
g(\boldsymbol{x})=100 \cdot f(\boldsymbol{x}) / f\left(\boldsymbol{x}_{\mathrm{RSS}}\right)
$$

ここで $f(\boldsymbol{x})$ は, 解 $\boldsymbol{x}$ に対応した総処理時間である.

\section{2 SA 法のパラメータの設定}

3. で示したLundy $ら^{17}$ により提案された冷却スケジュ 一ルを用いた SA 法に拈いて, パラメータの具体的な設 定は，以下のように行なった。

\section{（1）繰り返し数 $N$}

SA 法と他の手法との比較を行なうため, SA 法アル ゴリズムの繰り返し数 $N$ を, 200〜 50,000 回の間の種々 の値に設定し; アルゴリズムの実行を行なった.

\section{(2) 制御変数 $\boldsymbol{c}$ の初期值 $\boldsymbol{c}_{0}$}

制御変数 $c$ の初期值 $c_{0}$ は, 次の条件を満たすように, $c_{0}=10000$ とした.

$$
c_{0} \gg \max _{x}\{f(\boldsymbol{y})-f(\boldsymbol{x}) \mid \boldsymbol{y} \in S(\boldsymbol{x})\}
$$

この条件のもとでは, $f(\boldsymbol{x})<f(\boldsymbol{y})$ の場合でも次の受 理確率が 1 に近い値となり，ほとんどすべての状態が受 理される.

$$
p(\boldsymbol{x} \rightarrow \boldsymbol{y})=\min \left\{1, \exp \left(\frac{f(\boldsymbol{x})-f(\boldsymbol{y})}{c_{0}}\right)\right\}
$$

(3) パラメータ $\beta$

パラメータ $\beta$ の值は, $c_{f} \approx 1.0$ となるように, (18) 式を用いて， $\beta=1 / N$ とした. 実際, $c_{0}=10000, N=$ $200 \sim 50000, \beta=1 / N$ のとき, 制御変数の最終值 $c_{f}$ は, 約 1.0 という值となった. Fig. 2 より， $c_{f}=1.0$ のとき には, 目的関数值が増加する状態への状態推移はほとん ど起こらないてとがわかる.

\section{3 近傍構造と SA 法の性能との関係}

近傍構造の選び方と $\mathrm{SA}$ 法の性能との関係を調べるた め, 2. で示した三つの近傍構造を用いた SA 法を, 4.1 で示した条件のもとで生成された 30 個の問題例に対し 適用した. このとき, アルゴリズムの繰り返し数 $N$ は, 1,000 回，5,000 回，10,000 回，20,000 回抢よび 50,000 回とした. このような設定で得られた解の相対的総処理 時間の平均を問題の規模ごとに Table 1 に示す.
Table 1 Average relative makespan obtained by simulated

\begin{tabular}{|c|c|c|c|c|}
\hline \multirow{2}{*}{ Method } & \multirow{2}{*}{$\begin{array}{l}\text { No. of } \\
\text { iterations } \\
(\mathrm{N})\end{array}$} & \multicolumn{3}{|c|}{ Average relative makespan } \\
\hline & & $\begin{array}{l}20-\text { job } \\
\text { problem }\end{array}$ & $\begin{array}{l}40-\text { job } \\
\text { problem }\end{array}$ & $\begin{array}{l}60-\text { job } \\
\text { problem }\end{array}$ \\
\hline RSS & 50,000 & 100.00 & 100.00 & 100.00 \\
\hline $\begin{array}{l}S A-S_{1} \\
S A-S_{2} \\
S A-S_{3}\end{array}$ & $\begin{array}{l}1,000 \\
1,000 \\
1,000\end{array}$ & $\begin{array}{r}103.98 \\
96.71 \\
97.67\end{array}$ & $\begin{array}{r}103.96 \\
94.66 \\
96.22\end{array}$ & $\begin{array}{r}102.72 \\
95.36 \\
96.19\end{array}$ \\
\hline $\begin{array}{l}S A-S_{1} \\
S A-S_{2} \\
S A-S_{3}\end{array}$ & $\begin{array}{l}5,000 \\
5,000 \\
5,000\end{array}$ & $\begin{array}{l}99.08 \\
95.08 \\
95.20\end{array}$ & $\begin{array}{r}101.09 \\
93.08 \\
94.18\end{array}$ & $\begin{array}{l}99.83 \\
93.64 \\
94.35\end{array}$ \\
\hline $\begin{array}{l}S A-S_{1} \\
S A-S_{2} \\
S A-S_{3}\end{array}$ & $\begin{array}{l}10,000 \\
10,000 \\
10,000\end{array}$ & $\begin{array}{l}97.91 \\
95.03 \\
94.72\end{array}$ & $\begin{array}{l}98.70 \\
92.86 \\
93.15\end{array}$ & $\begin{array}{l}99.28 \\
93.74 \\
93.74\end{array}$ \\
\hline $\begin{array}{l}S A-S_{1} \\
S A-S_{2} \\
S A-S_{3}\end{array}$ & $\begin{array}{l}20,000 \\
20,000 \\
20,000\end{array}$ & $\begin{array}{l}97.23 \\
94.19 \\
94.40\end{array}$ & $\begin{array}{l}96.95 \\
92.46 \\
92.93\end{array}$ & $\begin{array}{l}96.73 \\
93.10 \\
93.32\end{array}$ \\
\hline $\begin{array}{l}\mathrm{SA}-S_{1} \\
\mathrm{SA}-\mathrm{S}_{2} \\
\mathrm{SA}-S_{3}\end{array}$ & $\begin{array}{l}50,000 \\
50,000 \\
50,000\end{array}$ & $\begin{array}{l}96.86 \\
94.06 \\
94.04\end{array}$ & $\begin{array}{l}94.62 \\
92.07 \\
92.54\end{array}$ & $\begin{array}{l}94.63 \\
92.77 \\
93.19\end{array}$ \\
\hline
\end{tabular}
annealing algorithms with different neighborhood structures

Table 1 から, 次のようなととがわかる.

（1）近傍構造 $S_{2}$ を用いた SA 法（SA-S $S_{2}$ 法）上近傍構 造 $S_{3}$ を用いた $\mathrm{SA}$ 法 $\left(\mathrm{SA}-S_{3}\right.$ 法) により, 近傍構造 $S_{1}$ を用いた $\mathrm{SA}$ 法 $\left(\mathrm{SA}-S_{1}\right.$ 法) よりあ良い解が得られて いる.

（2） 20 ショョブ問題では, 近傍構造 $S_{2}$ を用いた SA 法 $\left(\mathrm{SA}-S_{2}\right.$ 法) と近傍構造 $S_{3}$ を用いた $\mathrm{SA}$ 法 $\left(\mathrm{SA}-S_{3}\right.$ 法) により，ほぼ同程度の解が得られている.

(3) 40 ジョブ問題と 60 ショョブ問題では, 近傍構造 $S_{2}$ を用いた $\mathrm{SA}$ 法（SA-S $S_{2}$ 法）により, 近傍構造 $S_{3}$ を用 いた $\mathrm{SA}$ 法 $\left(\mathrm{SA}-S_{3}\right.$ 法) よりあやや良好な解が得られ ている.

\section{4 局所探索との比較}

SA 法と局所探索との比較を同一計算量のもとで行な うため, 計算量の基準として総処理時間 $f(\boldsymbol{x})$ の計算回 数を考え，乙れを 50,000 回とした. すなわち, SA 法 では，アルゴリズムの繰り返し数 $N$ を 50,000 とし, 局所探索では, 50,000 回の計算回数内で初期値をラン ダムに選びアルゴリズムの繰り返しを行なった.

このような設定のもとで得られた解の相対的総処理時 間の平均を, Table 2 に示す. Table 2 より, 次のよう なことがわかる。

(1) SA 法により, 同一近傍構造かつ同一計算量の局所 探索よりあ良い解が得られている. 乙れは, SA 法によ り，局所最適解に陥ることなく良好な解が得られること を示している. 
Table 2 Average relative makespan obtained by simulated annealing algorithms and local search algorithms

\begin{tabular}{|c|c|c|c|}
\hline \multirow{2}{*}{ Method } & \multicolumn{3}{|c|}{ Average relative makespan } \\
\cline { 2 - 4 } & $\begin{array}{c}\text { 20-job } \\
\text { problem }\end{array}$ & $\begin{array}{c}40-\text { job } \\
\text { problem }\end{array}$ & $\begin{array}{c}60-\text { job } \\
\text { problem }\end{array}$ \\
\hline LS- $S_{1}$ & 99.03 & 99.83 & 99.77 \\
SA-S & 96.86 & 94.62 & 94.63 \\
LS- $S_{2}$ & 94.96 & 93.73 & 94.53 \\
SA-S & 94.06 & 92.07 & 92.77 \\
\hline
\end{tabular}

（2）局所探索に扔いても，近傍構造 $S_{2}$ を用いるほうが 近傍構造 $S_{1}$ を用いるよりあ良い解が得られる.

\section{5 RAES 法との比較}

こてでは, RAES- $S_{1}$ 法および RAES- $S_{2}$ 法と SA$S_{2}$ 法との比較を行なう. 局所探索の場合と同様に, RAES $-S_{1}$ 法扔よび RAES- $S_{2}$ 法の計算量の基準とし て, 総処理時間 $f(\boldsymbol{x})$ の計算回数を考えることにする. RAES $-S_{1}$ 法打よび RAES $-S_{2}$ 法を用いて，4.1で設 定した 30 個の問題を解いたときの総処理時間 $f(\boldsymbol{x})$ の計 算回数を, Table 3 と Table 4 亿示す. また, RAES$S_{1}$ 法, RAES $-S_{2}$ 法打よびSA- $S_{2}$ 法に打ける計算回数 と相対的総処理時間の平均之の関係を Fig. 3 Fig. 5 に示す.な扔, Fig. 3〜Fig. 5 亿扔いて, SA-S の計 算回数はアルゴリズムの繰り返し数 $N$ であり, RAES$S_{1}$ 法扔よび RAES- $S_{2}$ 法の計算回数は, 総処理時間 $f(\boldsymbol{x})$ の計算回数の平均である.

Fig. 3〜Fig. 5 から，次のような乙とがわかる.

(1) RAES $-S_{1}$ 法により，非常に少ない計算時間で比較 的良好な解が得られている.

（2） RAES $-S_{2}$ 法により，RAES- $S_{1}$ 法よりも良い解が

Table 3 The number of computations of makespan in the process of RAES $-S_{1}$ algorithm

\begin{tabular}{|c|c|c|c|}
\hline \multirow{2}{*}{$\begin{array}{c}\text { Problem } \\
\text { size }\end{array}$} & \multicolumn{3}{|c|}{ The number of computations } \\
\cline { 2 - 4 } & Average & Minimum & Maximum \\
\hline 20-job & 139.7 & 20 & 248 \\
40-job & 387.1 & 118 & 703 \\
60-job & 714.9 & 296 & 1,417 \\
\hline
\end{tabular}

Table 4 The number of computations of makespan in the process of RAES $-S_{2}$ algorithm

\begin{tabular}{|c|r|r|c|}
\hline \multirow{2}{*}{$\begin{array}{c}\text { Problem } \\
\text { size }\end{array}$} & \multicolumn{3}{|c|}{ The number of computations } \\
\cline { 2 - 4 } & Average & Minimum & Maximum \\
\hline 20-job & 1,388 & 571 & 2,851 \\
40-job & 8,035 & 3,121 & 14,041 \\
60-job & 17,524 & 7,081 & 24,781 \\
\hline
\end{tabular}

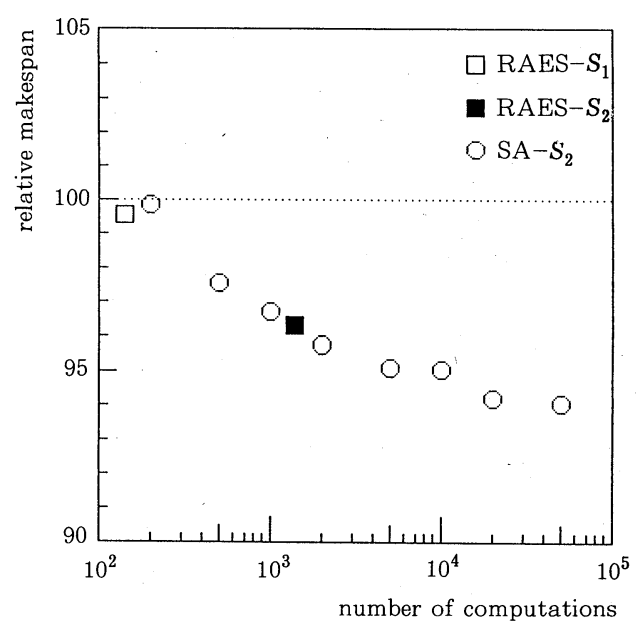

Fig. 3 The average relative makespan of 20 -job problems

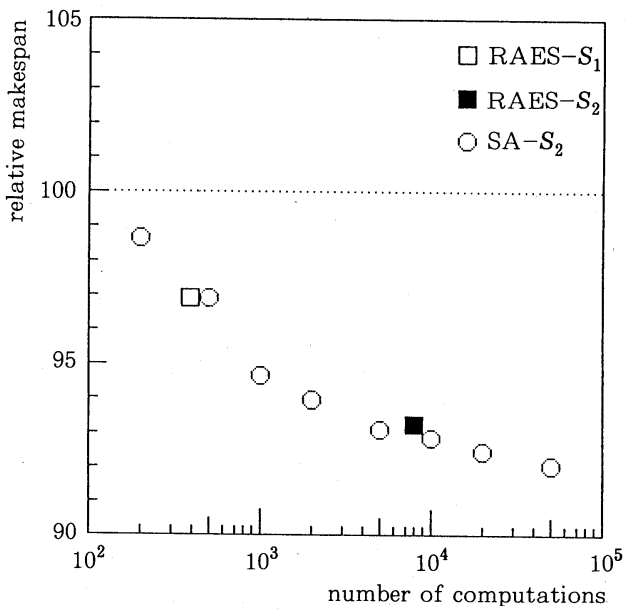

Fig. 4 The average relative makespan of 40 -job problems

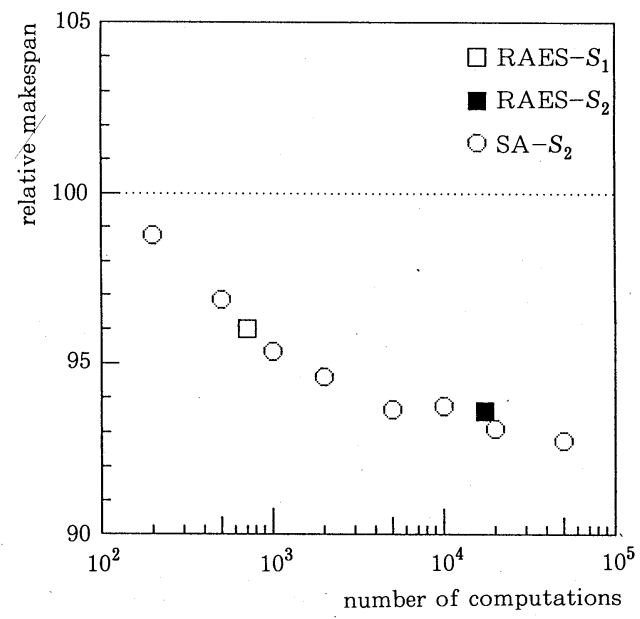

Fig. 5 The average relative makespan of 60 -job problems 
得られているが，計算回数が増加している.

(3) RAES $-S_{1}$ 法之同程度の計算回数のSA $-S_{2}$ により, $\mathrm{RAES}-S_{1}$ 法と同程度の解が得られている。

(4) RAES $-S_{2}$ 法と同程度の計算回数の $\mathrm{SA}-S_{2}$ により, $\mathrm{RAES}-S_{2}$ 法と同程度の解が得られている.

（5）アルゴリズムの繰り返し数を多くすることにより, $\mathrm{RAES}-S_{1}$ 法や RAES $-S_{2}$ 法よりあ良い解が, $\mathrm{SA}-S_{2}$ 法により得られている.

(6) 200 回の $\mathrm{SA}-S_{2}$ 法の繰り返しで, 50, 000 回のラン ダム・サンプルにより得られた解よりあ良い解が得られ ている.

\section{5. 結 言}

本研究では，総処理時間最小化を目的としたフロー・ ショップ・スケジューリング問題に対するシミュレーティッ ド .アニーリング法（SA 法）の有効性を示すため, Dannenbring ${ }^{12}$ によるRAES 法などの近似解法と SA 法との比較を数值実験により行なった．数值実験により, RAES 法などの近似解法之同程度の計算量の SA 法に より，少なくとあ同程度の解が得られることを示した。 また，SA 法の計算量を増やせば，他の近似解法より屯 良い解が得られること屯示した。 さらに，濃度の異なる 三つの近傍構造を用いた SA 法に対する数值実験により, 近傍構造の選び方と SA 法の性能との関係を明確にした.

本研究で用いた SA 法のアルゴリズムは, 事前に繰り 返し数を設定できるため, 利用可能な計算時間内でアル ゴリズムを終了させることができる．また，少ない計算 量であ RAES 法などの近似解法と同程度の解が得られ るため，利用可能な計算時間が短い場合でも有効であ ると考えられる.さらに，SA 法の計算時間は，繰り返 し数が 50000 回の場合でも，PC-9801 VX 21 を用いた BASIC コンパイラによる計算で数時間程度（20 ジョブ 問題で約 2 時間， 40 ジョブ問題で約 4 時間， 60 ジョブ 問題で約 6 時間）であるため，計算時間の点からあ現実 問題への適用が可能であると考えられる.

\section{参 考 文 献}

1) S. Kirkpatrick, C. D. Gelatt Jr. \& M. P. Vecchi : Optimization by Simulated Annealing ; Science, Vol. 220, No. 4598, pp. 671 680 (1983)

2) V. Cerny : Thermodynamical Approach to the Traveling Salesman Problem : An Efficient Simulation Algorithm ; J. of Optimization Theory and Applications, Vol. 45, No. 1, pp. 41 51 (1985)

3) S. Geman \& D. Geman : Stochastic Relaxation, Gibbs Distributions, and the Bayesian Restoration of Images ; IEEE Transactions on Pattern Analysis and Machine Intelligence, Vol. PAMI-6, No. 6, pp. 721 741 (1984)

4) B. Hajek : Cooling Schedules for Optimal Annealing ; Mathematics of Operations Research, Vol. 13, No. 2, pp. 311 329 (1988)
5) P. J. M. van Laarhoven \& E. H. L. Aarts : Simulated Annealing: Theory and Applications, Kluwer Academic Publishers, Dordrecht (1987)

6) E. H. L. Aarts \& J. Korst : Simulated Annealing and Boltzmann Machines, John Wiley \& Sons, Chichester (1989)

7) S. Geman \& C. R. Hwang : Diffusions for Global Optimization ; SIAM J. of Control and Optimization, Vol. 24, No. 5, pp. 1031 1043 (1986)

8) I. O. Bohachevsky, M. E. Johnson \& M. L. Stein : Generalized Simulated Annealing for Function Optimization ; Technometrics, Vol. 28, No. 3, pp. 209 217 (1986)

9) I. Matsuba : Optimal Simulated-Annealing Method Based on Stochastic-Dynamic Programming ; Physical Review A, Vol. 39, No. 5, pp. 2635 2642 (1989)

10) J. J. Hopfield \& D. W. Tank : Computing with Neural Circuits : A Model ; Science, Vol. 233, pp.625 633 (1986)

11) J. J. Hopfield \& D. W. Tank : Neural Computation of Decisions in Optimization Problems ; Biological Cybernetics, Vol. 52, pp. 141 152 (1985)

12) D. G. Dannenbring : An Evaluation of Flow Shop Sequencing Heuristics ; Management Science, Vol. 23, No. 11, pp. 1174 1182 (1977)

13) P. J. M. van Laarhoven, E. H. L. Aarts \& J. K. Lenstra : Job Shop Scheduling by Simulated Annealing, Operations Research (to appear)

14）人見：生産管理工学；コロナ社, pp. 100〜129 (1978)

15) S. M. Johnson : Optimal Two- and Three-Stage Production Schedules with Setup Times Included ; Naval Research Logistics Quarterly, Vol. 1, pp. 61 68 (1954)

16) 岡村, 山品: フレキシブル生産システムの運用法; 精密機 械, 48 巻, 2 号, pp. 190〜197 (1982)

17) M. Lundy \& A. Mees ': Convergence of An Annealing Algorithm ; Mathematical Programming, Vol. 34, pp. $111 \sim 124(1986)$

18) R. W. Eglese \& G. K. Rand : Conference Seminar Timetabling ; J. of Operational Research Society, Vol. 38, No. 7, pp. 591 598 (1987) 